\title{
"Mother, I want to marry her, but only if you wish": A Case of Visual Analysis to Understand Families in Contemporary Kerala
}

Shiju Joseph, ${ }^{*}$ T Sasidharan ${ }^{\dagger}$ and Maya Menon ${ }^{\ddagger}$

\section{Abstract}

The study suggests looking into culturally sensitive data sources like popular films that open a window into the social psyche. As an illustrative case, the climax sequence of a popular Malayalam film Aniyathipravu is analyzed using the method of visual analysis. The analysis is guided by the hermeneutic approach of psychoanalysis and by inputs from evolutionary psychology. The analysis attempts to explore the aspects of individuation of the son, female identity formation and the familial consequences of these aspects in the contemporary society. It reveals how the son is caught in the ambivalence of wanting to be separate from his mother and to be dependent on her, and how the mother is evolved into the cultural stereotype of mother-in-law. The study also shows that motherhood overshadows all other aspects of the female identity in the contemporary society. Study has demonstrated the use of visual analysis to interpret data from popular culture. It indicates the need to psychologically analyze family structure in the contemporary society.

* Assistant Professor, Department of Psychology, Govt. College for Women, Trivandrum, Kerala; pjosephshiju@gmail.com

† Reader, Department of Psychology, University of Calicut, Kerala

‡ Assistant Professor, Department of Psychology, Govt. College for Women, Trivandrum, Kerala 
Keywords: Family, Enmeshment, Identity, Individuation, Film, Kerala, Visual analysis

\section{Introduction}

Cinema, the most influential cultural product of the present times, has been the top means of entertainment for the past few decades in any part of India. Cinema not only reflects culture, but also shapes culture (Gokulsing \& Dissanayake, 2004). The present work seeks to derive some psychological information related to the portrayal of family dynamics in Malayalam popular cinema and thus to understand the regional society of Kerala that produces, enjoys and is even shaped by this cinema.

To a large extent, the contemporary society's values, dreams and fantasies are influenced and are even decided by cinema. This medium is the most instrumental in propagating the ideas of love and heroism, society and individual, family and state, status and functions of the two sexes, parent-child interaction and construction and maintenance of social relations (Joseph, 2006). This is strong enough a reason for a psychologist to study popular cinema.

Cinema is considered as part of 'popular culture'. Simply stated, popular culture is the culture that is widely favoured or well-liked by many people. It is the culture actually made by the people for themselves (Williams cited in Storey, 1988). The popularity of a particular breed of films can be an indication of its exploration of psychological themes that are buried deep within the society. Through the popular films, these inner themes are presented, covered-up as entertainment. When the number of spectators that appreciate the film is more, the stronger is its link with these inner themes. That is why many psychologists of the present believe that narrative thinking-'storying'-is the best way to gain an understanding of a society (Kakar, 1989).

The present work tries to infer back from the product cinema to the society that produces it. Such works are expected to provide useful insights into the society's psyche, its dreams, and fantasies, its negotiations with reality and sometimes its unconscious desires, repressions and even its psychopathology. 


\section{Popular Culture and Cinema}

It is often said that cinema is a modern myth. A myth is a dream that has gone public. While dreams are made to be forgotten, myths are to be remembered (Strauss, 1963). In his book 'Mythologies' written in 1957, Rolland Barthes analysed the functioning of myth in detail. Cultural artefacts produce meaning through their mythic function that mediates reality. Myth "purifies (things), it makes them innocent, it gives them a natural and eternal justification" (Barthes, 1999, p.58). This naturalization of history is the ideological function of myths. This concept of myth as a process of signification by which a society explains its history and culture became much useful in the studies of popular culture, especially popular films, given its mythical structure and content. In fact, many critics view cinema as a modern myth.

\section{Psychoanalysis as an Interpretive Tool of Art Forms}

Sigmund Freud had analyzed several literary and other works of art to show how the author's inner life is reflected in his work. One classic example of Freud's literary analysis is the essay Dostoevsky and Parricide (1928). Freud shows here how the language was used by the author to 'hide in it'. There is no better way for the true parricide to hide than to write about parricide, the theme of Dostoevsky's classic novel Brothers Karamasov. The method used by Freud was adapted by psychoanalytic critics to explain cultural products including films. The hermeneutic suspicion of psychoanalysis that a text can mean something other than what is stated guided the whole process of interpretation always. Later, as psychoanalytic film theorists attempted analyzing film experience psychoanalytic terms and metaphors like dream, fantasy, identification and introjection were used as analogies.

\section{Analysis of Popular Films in India}

Thomas (1985) lists some of the attributes of Indian popular cinema viz. emphases on emotion and spectacle rather than tight narrative; on how things will happen rather than what will happen next, on familiarity and repeated viewing rather than originality and 
novelty. It concentrates on a moral disordering to be temporarily resolved. The spectators are addressed and moved through the film primarily via emotions. The narrative gathers its power from the very familiarity of themes deeply rooted in the psyche and traditional mythology.

Kakar approaches popular Hindi cinema as a collective fantasy, a daydream, a primary vehicle for shared fantasies of a vast number of people who are both culturally and psychologically linked (Kakar, 1989). Dismissing popular films as unrealistic is not right. "To limit and reduce the real to that which can be demonstrated as factual is to exclude the domain of the psychologically real" (Kakar, 1989 , p.30), the actuality of one's inner life. Popular films may be unreal in a rational sense, but they are certainly not untrue. The true inner life often remains latent beneath the surface of the oftrepeated stories of cultural conformity. Kakar regards the Indian cinema audience not only as the reader but also as the real author of the text of popular films while their ostensible creators are doing the function akin to that of a publisher. In their search for the 'hit', the film makers repeat and vary the daydreams.

However, the film maker may not be aware of the meaning that his film makes in the minds of the spectators. His function is merely to present the unresolved inner conflicts that have roots both in the universal human psyche and in the specific culture. In that sense, popular cinema serves the mythical function that mediates reality. This myth is a window opened into the social psyche.

\section{A Conceptual Framework for Interpreting Popular Cinema}

The language Malayalam, one of the four major Dravidian languages, has over 30 million speakers. It is estimated that by 2012, around 3700 feature films have been produced in Malayalam language. In Malayalam popular films, like in every other regional films, each character, each narrative twist and each dialogue is a planned ingredient intended to arouse some 'sentiments' of the spectator. In all stages of production of a popular film, an imaginary spectator is envisioned, ingredients are added according to his (imaginary) 'taste', narrative is directed in his interest and the climax is designed so as to please him. Thus, the spectator, being 
the 'deciding factor' of the narrative, is the virtual author/creator. His/her anticipated imaginary feedback functions as the creative force in this process. The film analyst in turn attempts to interpret the dream of the spectator (or at times the spectator himself). This dream happens to be the collective dream of the society, the depiction of which the film making team have carried out. The notion of spectator/society as creator however does not downplay various pervasive thematic interests of different film makers to which the spectators choose to identify.

The term identity is used in the study as something that describes an individual's comprehension of him or herself as a discrete, separate entity. According to Erikson, identity is the formation of a coherent self that allows an individual to make life's choices independently and experience a sense of autonomy. It provides one with a sense of self direction (Erikson, 1968; Hoare, 2002). Individuation is a term used to signify the process of maintaining an integrated sense of self with significant attachment with others but without enmeshment or being fused with them. It is the complementary process of separation, allowing one to establish who and what this 'separated' self is (Mahler et al, 1975; Rice et al, 1990).

\section{Objective of the Study}

The objective of the essay is to analyze the aspects of individuation of the son and identity of the mother in a popular Malayalam film Aniyathipravu, focusing on its depiction of the mother-son bonding so as to gain psychological insights regarding films, spectators and the Kerala society in general.

\section{Method}

The present work is a case study of a Malayalam film Aniyathipravu released in 1997, in which the aspects of individuation and identity related to two characters- the hero and his mother- are analysed. The film Aniyathipravuis one of the most popular films produced in Malayalam within the last two decades. Belonging to the love story genre, the film marked a significant turn in the Malayalam Popular 
film history. The film drew the attention of the investigators due to its heavy cultural loading.

The analysis tries to find out reasons by utilizing psychoanalysis as an explanatory mechanism. For analysing the specific aspects of the film, the method of visual analysis (Smith, 2007) is followed.

\section{Analysis and Interpretation}

\section{Aniyathipravu: Reading Identities and Families in Contemporary Kerala}

The title of the film can be translated roughly as 'The Dove-like Little Sister'. 'Aniyathipravu' scripted and directed by Fazil (1997), the family drama specialist of the middle cinema, grabbed great success at the box-office. Its advertisements hailed the greatness of motherhood and suggested that the film contained a moral lesson for lovers. The carefully scripted and shot climax is often hailed by popular film magazines as one of the best dramatic climaxes ever made in Malayalam cinema. The climax sequence uploaded in YouTube (Knbinoj, 2012) has had more than 1,50,000 views within two years and has generated comments like "best ever touching realistic climax ever happened in Indian cinema" and "really great climax for a romantic film."

A comprehensive psychological analysis of the film focusing on the character played by actress Shalini has been made by the first author in another work (Joseph, 2006). It was observed that the persona of Shalini was that of the sister-favourite of the Malayali spectator and that it has heavy socio-cultural implications. The present study attempts to explore another aspect of this film individuation of the son and identity of the mother.

For facilitating discussion based on the film, the story line of the same is given in Appendix 1.

Aniyathipravu is supposedly a love story. The hero Sudhi and the heroine Mini are college students. But, they have no similarity with the conventional characters often seen in some romantic college movie. They never kiss or hug each other. Moreover, they are not the characters who keep the narrative in motion. This unusual process merits a closer attention. 
The opening sequence of the film is significant in this aspect. Sudhi's mother is introduced as the authority who could take a decision on Sudhi's marriage. It is her likes, dislikes, wishes and priorities that set the narrative in notion. Again, it is the mother who steals the show in the climax sequence that lasts about nine minutes. There has been a race between Mini and Sudhi's mother for the status of the heroine, in which the mother wins ultimately.

Here we need to have a close look at the climax sequence. Sudhi's mother Chandrika wants to see Mini before her marriage. Chandrika says she wants to see Mini, and thereafter needs to find out a better girl for her son. So, Sudhi, his parents and friends go to Mini's house as if to give back Mini's gold chain that happened to be with him and also to apologize for all that happened. A highly emotional drama is set in. The two families try to be warm in their interactions. But, the exchanges remain ill at ease. Chandrika is at the centre of most of the frames. Mini is shown in mid shots. Spending some time there, the visitors are about to leave. Mini's Ammachi (mother) asks Chandrika - "You didn't even talk to my girl; can't you bless her?" Chandrika raises her hands, lowers them and bursts with emotions -"How can I bless her, what should I tell her? Isn't she my girl? Give her (to me). I will take care of her." In a Sudden flow of auspicious background music, the focus is turned to Ammachi who reacts in the same manner - '(You) take her, and give her boy to her'. One cannot escape the nuances of the utterances by the two mothers regarding the claim and possession of their children. Sudhi's mother asks Mini as her property while Mini's mother indicates that Mini should be given her due, ie, Sudhi, from his mother ('Give her boy to her'.)

As everybody is looking on in disbelief, Ammachi explains them that only mothers could understand all these. An air of happiness fills the situation. All through this time, the two mothers are at the centre of attention as the decision-makers, shown in close shots. Sudhi and Mini are apparently insignificant and are shown in long shots along with others. After resolving the issue, Chandrika looks on to Sudhi and invites him toward her with extended arms. She hugs him and asks - "Amma made you worry so much, aren't I?" She also tells Sudhi's father -"I can't find out a better match for him (than Mini)". 
It is found that out of a total of around 50 Shots in the second part of the climax that lasts three minutes, the mother becomes the central object in not less than $40 \%$ shots, mostly close shots, whereas the hero appears in less than 10\% shots. Film theorist Metz (1982) says that while viewing a film the spectator identifies with the projector. So, the most visualized characters are the most identified with ones. So, naturally and easily, the spectator identifies with the mother.

As the narrative progresses, who is resolving the puzzle of the film? Who is the mighty demanding personality? Who is at the centre of attention? None other than Sudhi's mother. In a commercial film, these are the usual duties assigned to the hero himself. So in this film, the mother captures the position of the heroine and eventually assumes the role of 'the hero' himself. (The word 'hero' is used here for the common central male character in mainstream film.) Aniyathipravuis arguably the first Malayalam film having a climax in which the mother acts exactly like 'the hero' and does whatever a hero is supposed to do. After resolving the puzzle of the film, the mother-hero extends her arm and invites the 'son-heroine' for a hug making him rest in her arms and bosom. The invitation is not for a usual sideways hug - holding close between a mother and mature son, but for a straight direct embrace. It is to be noted that Sudhi and Mini are never allowed in the whole film to exchange any hug or kiss.

We will have a brief look into the meaning of this particular positioning of the mother character.

\section{The Puzzle of the Film - An Altered Discourse on Love}

Usually, the most important and possibly the sole opposition to the love of the hero and heroine must have been the difference in their religions. (The hero Sudhi is a Hindu and the heroine Mini is a Christian). But strangely enough, this never comes up in the discourse. The narrative revolves around the oppositions created by attachments within the families of the lovers. Let us examine what happens in the boy's family.

The film starts with the visuals of the hero's mother organizing a puja intended to remove the blocks if any for the hero's marriage. 
He is definitely not that old; he wants to study. Father and son play a drama and manage to get the sanction for studies from the mother. He goes to study, but accidentally meets a girl, falls in love with her. When his life is under serious threat from the girl's brothers, Sudhi approaches his father for support. Even as he rejects, Sudhi is confident about his mother ("I am sure, my mother can solve all the problems"). But, she also summarily rejects his plea. "Leave that girl back at her home", she suggests. "It was under my direction that father too asked you to return home without the girl". Disappointed, he goes back. On the way, he has a narrow escape from a murder attempt.

The mother's behaviour is strange enough in that she is not even ready to hear anything about her son's choice, and simply rejects all possibilities of finding out a solution to the problem of love and marriage, whereby leaving her son's life in danger. But at the end, she herself asks the same girl for her son and solves the problem. Why couldn't she think about such an option earlier?

The answer is clear. She cannot accept a 'choice' by the son. It is she who should 'give' her son a partner. She considers it as her responsibility. Even the son seems to be convinced of it. His response when he is allowed to take up higher studies is this: "Mother, I know, you will bring here a girl like Lakshmi for me". But he fell in love with a girl of his own choice. He tells his friends about the girl: "She is like chosen by somebody for me, like the result of prayers by somebod" Sudhi declares so before his father too: "She is the girl I am bringing to show to my mother".

\section{Struggle for Individuation}

Putting instances like these into a closer analysis, the mother - son dynamics could be revealed. The son likes the mother the most. But, somewhere down his heart, he wants to replace the mother with a girl of his own choice. Obviously, mother cannot allow it. She assumes the power of 'decision maker'; deploys his agent, the father, to claim her position. On being perplexed by the ambivalence towards his mother and the moralistic pressures of submitting to the parents, the son retreats from his new found love. Thus the mother reclaims her position. But, once it is done, the 
mother starts becoming insecure and even guilty. She is sure that the son has to be made free at some point of time, that it is inevitable. She cannot keep him in confinement forever. So, she gives the son back his love, thus making him feel that it is the mother who has presented him his love. She can be happy in that her son will be loyal to her thereafter forever; her position will be out of threat always. It suggests that the real opposition is no one else, but the mother herself. And what the spectators witness is a drama to retain the mother's position. So, it appears as a struggle of the mother to keep her child as her own.

Meanwhile Mini had already made herself eligible for the role of a wife by making a long talk on the topic 'children are the properties of parents' before the fisher folk who rescued them. So, she has proved that she is no more a threat to the mother, the original owner. Thus, the hero and heroine prove their eligibility through acts of renunciation.

What is it that triggers the mother's struggle for reclamation of the child? A concept introduced by Kakar finds a culture-specific element in the Indian mother-son relationship. Kakar (1997) identifies a factor called 'maternal enthrallment', described by the paradoxical abstractions developed in an Indian son out of this relationship: As the son matures, he develops and experiences the wish to get away from the mother together with the dread of separation; hate for the mother one longs for so much; incestuous desire (and near-incestuous experience) coexisting with the terror inspired by assertive female sexuality (p.74). In this process, mother also takes an active role by keeping him as her own property even after the childhood, since a son in the Indian culture is the guarantor of a woman's identity (Kakar, 1989, 1997).

A close examination of Sudhi's (the hero's) family shows that Sudhi and his mother share a relationship with diffuse boundaries. Theirs is an enmeshed relationship (Minuchin, 1974). Enmeshed family systems, which are characterized by extreme emotional connectedness and loyalty (Olson, 1999), have historically been believed to prevent individuals within such a system from being able to achieve successful separation-individuation (Rice, Cole, \& Lapsley, 1990). Individuals from such systems find it extremely difficult to establish an identity of their own and this reflects in 
their ambivalence in decision-making situations. They are wrenched between the simultaneously ensuing need to separate from and fear of losing the loved one, the primary attachment figure. This is the dilemma that the character, Sudhi in this movie demonstrates. He is closest to his mother, who has overpowered him with her love and he is enthralled (Kakar, 1997) by her presence in his life. But as he moves into adolescence, he falls in love with Mini, who naturally both the mother and son fear, will replace the mother in Sudhi's life. Eventually, Sudhi decides to retreat away from his new-found love, and the mother impends upon her son. This rapprochement can be likened to the separation anxiety experienced by the child who tests the new found freedom of individuation owing to increased physical mobility. Mahler's separation-individuation process is known to repeat itself in adolescence and young adulthood, a process referred to as second individuation (Blos, 1967) and in the successful resolution of the dilemma of separating and differentiating from the mother, without losing her love, lays the foundation of a complete identity.

So, here are two characters that are caught in the process of separation-individuation. In order to gain a better understanding as to why mother is not allowing of her son to individuate, another aspect of the mother's identity in the film need to be looked upon.

\section{Identity of the mother(s): What is there in a name?}

Take a look at the identity of the mothers in the film. The hero's mother is the wife of a businessman. Her sole company is the son, it seems. We do not know anything about her family or friends. Most notable is that the spectators could hear the name of Sudhi's mother 'Chandrika' only at one instance in the film. On all other occasions she is referred to as Amma (mother). Even though she seems to be very assertive in the matter of her son, one would wonder whether that kind of assertiveness would have been possible in her young adulthood. It can well be assumed that her present status of the mother/owner of a grown up son gives her this assertiveness, courage and the power to speak. Kakarhas observed that a son in the Indian culture is the one who gives the woman an identity; the son is the guarantor of her identity (Kakar, 1989, 1997). 
Mini's mother is always known as Ammachi (means mother; this addressing is specific to Christian families in Kerala.) Her name is never spelt in the whole film. Still she seems to be very powerful and commanding. Naturally, she is the mother of three grown up sons! Both mothers are apparently nameless, as though representing the universal community of mothers. They are known by their status identity, which is their sole identity in the film. Thus it appears as the representation of a one dimensional and exaggerated motherhood.

This is an indicator of the identity of an ordinary woman in the contemporary Kerala society. Being just like a property that is transferred from the custody of the father to that of husband, she apparently has never got an identity till she becomes a mother. The status of a mother gives her an identity and confidence since she is now the owner of something for the first time in her life. No wonder that she is very possessive of this property, the loss of which causes the loss of her own identity.

The science of evolutionary psychology says that people's behaviours are programmed by evolutionary principles. The gene level selection theory of evolution says that the ultimate aim of every person is to transmit his/her genes to the next generation and thus to survive past generations (Dawkins, 1976). So parents invest a lot in children who are mostly their own genetic replica. A mother who usually has no other way to ensure her survival -like profession, income, power, social identity or friend circle naturally tends to ensure their survival through children (and children only).

Thus it becomes natural that a mother can never tolerate the loss of her son to another woman. It is a loss of identity, power, survival and what not. It is only natural for a mother-in-law to aggress and resist the invader, the daughter-in-law, an idea prime-time television serials vigorously promote.

India is a society where arranged marriage is the norm at large and a love marriage or love affair that does not necessarily culminate in marriage is seen as an exception or deviation. However, research work that explores the phenomenon of love marriage, including its antecedents and consequences in the emotional and social realms 
are sparse. Informal and clinical observations (M. Menon, personal conversation, September 19, 2009) have shown that the child's attempt to individuate has a significant bearing on his/later choices like love marriage. It can be a rebellion, a struggle for independence, one crucial sign of which is the freedom to choose one's life partner, the other being the freedom to choose one's career, ie., to study what one wants to. The extent to which these two facets of freedom are taken into consideration by the current parenting practices is an area that demands further studies.

The study can be concluded by looking the problem from the other side- What if the father, instead of mother, were the one who was suffering from this identity problem? The issue would have reflected in the career area of the son, not the area of marriage. An example is the film 'Thanmaathra' (2005) in which the father character played by Mohanlal suffers from Alzheimer's disease, the psychological meaning of which in the film situation is nothing but a loss of identity in adulthood. The father in his youth wanted to enter the civil services, but he could not. Now he wants his son to achieve it and fulfil his dream. Thus the son has to live out his father's dream. In fact, this is an indication of what happens in contemporary Indian society where parents who could not live out their dreams are handing the mover to their children. If one wanted to be a singer in the childhood and could not achieve it, here is the way now - S/he can send her child to the music reality show and achieve a trangenerational vicarious satisfaction through the child.

\section{Implications}

The above said responses arise from cultural historical reasons which are not easy to be discussed here. Not many studies have gone into this area. Since family holds the pivotal role in the formation of the individual and the society in the Indian culture, much research has to focus on the present family structure in light of psychological theories. The investigator strongly feels that we need to explore further into the fields of female identity formation, separation anxieties of children and parents, and the emotional and familial consequences of these processes in the contemporary society. For understanding psychologically relevant structures like families, the potential of newly emerging qualitative research 
methods that make use of multiple data and multiple theories can be adopted. This can provide social scientists and psychologists with some useful insight into culture and society.

\section{References}

Barthes, R. (1999). Myth today. In J. Evans \& S. Hill (Eds.), Visual culture: The reader, (pp. 51-58).London, England: Sage.

Blos, P. (1967). The second individuation process of adolescence. Psychoanalytic Study of the Child, 22,162-186.

Dawkins, R. (1976). The selfish gene. New York, NY: Oxford University Press.

Erikson, E. H. (1968). Identity, youth, and crisis. New York,

NY: Norton.

Fazil. (1997). Aniyathipravu [Motion picture]. India: Swargachithra Films.

Appachan.(Producer), \& Fazil.(Director).(1997). Aniyathipravu [Motion picture]. India: Swargachithra

Freud, S. (1928/1996). Dostoevsky and parricide. In Penguin Freud Library, 14. London, England: Penguin Books.

Gokulsing, K. M., \& Dissanayake, W. (2004). Indian popular cinema: A narrative of cultural change. New Delhi, India: Trentham Books.

Hoare, C. H. (2002). Erikson on development in adulthood: New insights from the unpublished papers. New York, NY: Oxford University Press.

Joseph, S. (2006). Psycho-cultural analysis of popular films in Malayalam: An introductory study. (Unpublished M.Phil thesis).University of Calicut, Calicut, India.

Kakar, S. (1989).Intimate relations: Exploring Indian sexuality. Chicago, IL: University of Chicago Press.

Kakar, S. (1997).Culture and psyche. New Delhi, India: Oxford University Press. 
Knbinoj. (2012, November 21). Aniyathipravu climax [video file]. Retrieved from http://www.youtube.com/ watch? $=\mathrm{v}=\mathrm{JbmdMtGwII.}$

Levi-Strauss, C. (1963). Structural anthropology. London, England: Penguin.

Mahler, M. S., Pine, F.,\& Bergman, A. (1975).The psychological birth of the human infant. New York, NY: Basic Books.

Metz, C. (1982). The imaginary signifier: Psychoanalysis and the cinema. Bloomington, IND: Indiana University Press.

Minuchin, S. (1974).Families and family therapy. Boston, MA: Harvard University Press.

Olson, D. H. (1999). Empirical approaches to family assessment. Journal of Family Therapy, 22 (4), 447-449. http:/dx. doi.org/ 10.1111/1467-6427.00164.

Rice, K. G., Cole, D. A., \&Lapsley, D. K. (1990). Separation individuation, family cohesion, and adjustment to college: Measurement validation and test of a theoretical model. Journal of Counseling Psychology, 37(2), 195-202. http:/dx. doi.org/ 10.1037/0022-0167.37.2.195

Smith, J. A. (2007). Qualitative psychology: A practical guide to research methods. New Delhi, India: Sage Publications.

Storey, J. (1993).An introduction to cultural theory and popular culture. London, England: Harvester Wheat Sheat.

Thomas, R. (1985). Indian cinemas: Pleasures and popularity. Screen, 26(3\&4), 116-137.

\section{Appendix I: Story Line of the film Aniyathipravu}

The title could roughly be translated as 'The Dove like Little Sister'. After the title sequence in which a melodious love song is pictured, a puja can be seen performed at the behest of the hero's mother Chandrika (played by Sreevidya). She is insisting her son Sudhi (Kunchacko Boban), the hero, to marry soon, but he wants to do his MBA. With the support of father Raghupal (Thilakan), he manages to convince his mother and joins a college away from home. Along 
with two friends, Radhu (Sudheesh) and Chippayi (Harisree Ashokan), Sudhi stays there at the house of a retired Colonel. Meanwhile he meets a girl at a bookshop and instantly falls in love with her. Later, an accidental expression of his love ends up in the three friends being beaten up by the girl's brothers, Kuttappayi, a doctor, Iyo, a Police Inspector and Varkey, the youngest. The heroine, Mini, takes a vow in front of the statue of Christ that she will not commit wrong. Sudhi and friends enact a man-missing drama to entrap Iyo. As per the request of Mini, Sudhi solves the issue and thus spares Iyo from suspension. Sudhi expresses his love; the fearful and over-submissive Mini is unable to answer and takes a long leave from her studies. Sudhi enters straight her house and gives her a letter written 'can't you write at least?' Seeing this, Varkey and team beat Sudhi severely at the college yard. Mini, after several rounds of prayers, comes to visit Sudhi and so starts their love. Friends try to teach them how to love. During one of these sessions, while Sudhi was running after Mini to touch her for the first time, Varkey comes in their way and beats Sudhi. Mini intervenes to save Sudhi and declares that she is in love with him. Mini is forsaken by her family who are chasing the lovers thereafter to kill Sudhi. To Sudhi's despair, his father also denies to help the two. They flee to Chippayi's home in the coastal area. There fishermen offer help in conducting their marriage. Meanwhile Sudhi goes to meet his mother who, to his disbelief, asks to stay back from the relation. She reveals that father was also reacting as per her instructions. Back at Chippayi's place, Sudhi and Mini decide not to marry. Though Chippayi's father and the whole fisher-folk feel humiliated at first, everyone agrees to Mini's words that they should not cause worry to their families. Both go back to their respective homes and make their families happy. Mini's marriage is decided immediately. Sudhi's mother becomes insecure and insists to see her so that she can choose a better girl for her son. Sudhi along with his parents and friends visit Mini's home. In a highly emotionally charged final sequence, Sudhi's mother asks Mini for her son. Mini's mother obliges to it and the film ends with a happy note. 